\section{Unusual Isoxazoline Formation by Intramolecular Cyclization of (9E)-Erythromycin A Oxime}

\author{
Fattori Raimondo, Pellacini Franco,* \\ Romagnano Stefano, Fronza Giovanni ${ }^{\dagger}$ \\ and RALlo RoBERTA ${ }^{\dagger}$ \\ Zambon Group, \\ Via L. Del Duca 10, 20091 BRESSO (MI), Italy \\ ${ }^{\dagger}$ Centro Studio Sostanze Organiche Naturali, \\ Dipartimento di Chimica, Politecnico, \\ Via Mancinelli 7, 20131 Milano, Italy
}

(Received for publication February 26, 1996)

In the last few years there has been a renewal of interest in macrolide antibiotics, following the successful introduction in the market of second generation derivatives of erythromycin $\mathrm{A}^{1,2)}$ with improved pharmacokinetic and antimicrobial activity, like roxythromycin, clarythromycin and azithromycin.

Azithromycin differs structurally from erythromycin $A$ by the insertion of a methyl substituted nitrogen at $9 \mathrm{a}$ of the lactone ring, creating a 15 -membered macrocycle. This insertion was obtained ${ }^{3)}$ by a Beckmann rearrangement of $E$-oxime 1 in which the nitrilium ion intermediate was trapped intramolecularly by the 6-oxygen giving rise to the iminoether $\mathbf{2}$ that was reduced subsequently to the amine 3 and finally methylated to 4 .

When the Beckmann rearrangement is performed in ether ${ }^{4)}$, in the presence of pyridine and with addition of $p$-toluensulphonyl chloride at $-45^{\circ} \mathrm{C}$, the nitrilium ion is trapped also by the $\mathrm{O}-11$, giving a mixture of 2 and 5. Carrying out the reaction in the same conditions at
$0 \sim 5^{\circ} \mathrm{C}$ the lactam 6 can be isolated ${ }^{3)}$ as the major product. Similar compounds with the annular nitrogen at $8 \mathrm{a}$ of the macrolide ring were synthesised by the Beckmann rearrangement of the $Z$-erythromicin oxime, which is readily available by the basic isomerization of the corresponding $E$ isomer ${ }^{5)}$.

During our work on erythromycin derivatives we unexpectedly isolated isoxazoline $\mathbf{7}$ in conditions very similar to those required for the preparation of iminoether $2^{3)}$ but the choice of base. In fact $\mathbf{2}$ is obtained by DлокIC ${ }^{3)}$ in $86.5 \%$ yield using excess of sodium hydrogen carbonate and tosyl chloride in a 1:1 water-acetone mixture. If at variance with respect to the conditions reported above the $E$ oxime $\mathbf{1}$ is treated with tosyl chloride in a 1:5 water-acetone mixture with excess potassium hydroxide as a base we obtained 7 in $60 \%$ yield. The structure of 7 was determinated on the basis of ${ }^{1} \mathrm{H},{ }^{13} \mathrm{C}$ and ${ }^{15} \mathrm{~N}$ NMR studies. The ${ }^{15} \mathrm{~N}$ spectra were run on a concentrated solution of 7 in $\mathrm{CDCl}_{3}$ (ca. $300 \mathrm{mg} / 0.5 \mathrm{ml}$ ) under proton broad-band decoupling and with the suppression of the heteronuclear NOE (the ${ }^{15} \mathrm{~N}$ nucleus has negative ${ }^{1} \mathrm{H}^{15} \mathrm{~N}$ nuclear Overhauser effect leading to a decrease in signal intensity or even to a complete disappearance of the signal). The ${ }^{15} \mathrm{~N}$ spectrum of 7 shows two peaks at -361 and $-24 \mathrm{ppm}$ relative to the external neat nitromethane. The resonance at $-361 \mathrm{ppm}$ is characteristic ${ }^{6}$ of amino nitrogen atoms and can be assigned to the $\mathrm{N}\left(\mathrm{CH}_{3}\right)_{2}$ group of the desosamine residue. The resonance at $-24 \mathrm{ppm}$ cannot be attributed to any structure deriving from the Beckmann rearrangement; this rearrangement, as mentioned before, should afford some imino ether (6,9- or 9,11-imino ethers, ${ }^{15} \mathrm{~N}$ region $-130 \sim-170 \mathrm{ppm}^{6}$ ) or lactamic derivatives $\left({ }^{15} \mathrm{~N}\right.$ region $\left.c a .-250 \mathrm{ppm}^{6)}\right)$ de-
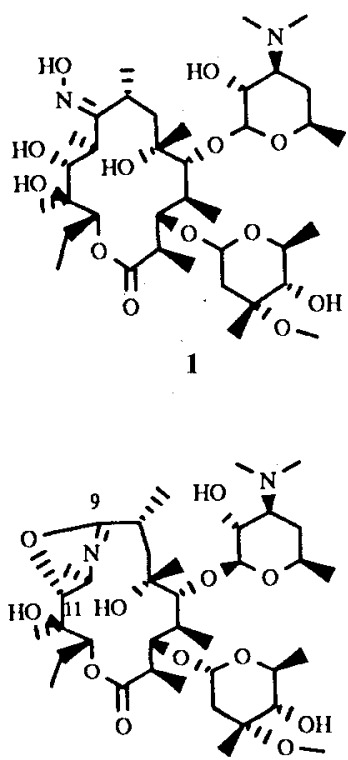

5

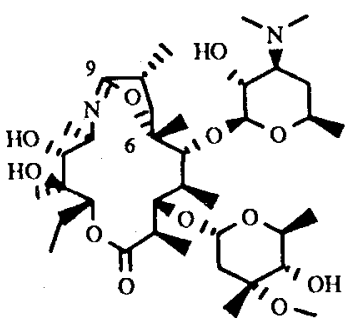

2

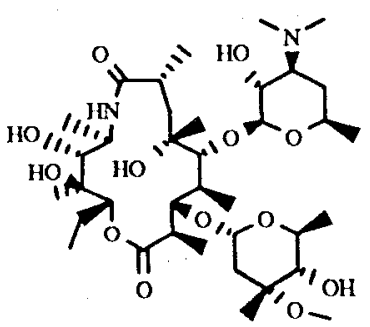

6
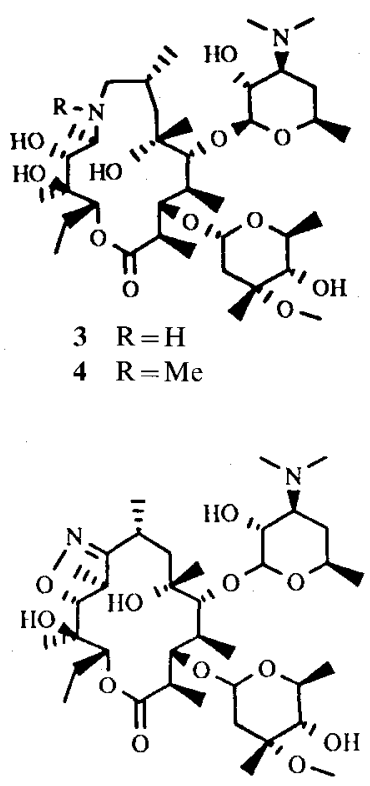

7 
Fig. 1.

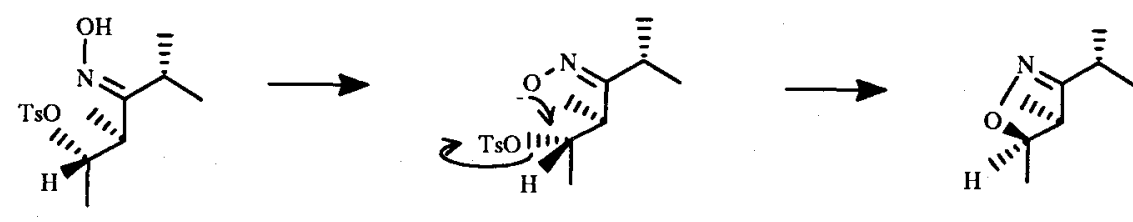

Fig. 2.

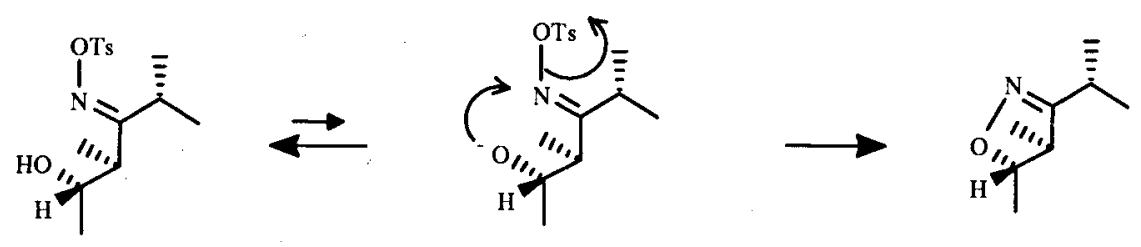

pending on which hydroxyl group is captured by the intermediate nitrilium structure ${ }^{3)}$. The observed resonance at $-24 \mathrm{ppm}$ falls in the region of an oximic and isoxazolinic nitrogen atom $\left(-20--45 \mathrm{ppm}^{6,7)}\right.$ and is in agreement with our structure.

The formation of 7 from 1 can be explained by, at least, two different mechanisms (Figs. 1 and 2).

The first requires the isomerization of the $E$ oxime to $Z$ oxime, followed by tosylation of $\mathrm{O}-11$ with subsequent nucleophilic substitution on $\mathrm{C}-11$ (Fig. 1). The second mechanism, simply envisions the tosylation of the $E$ oxime oxygen, the normal pathway in the Beckmann formation of iminoether $\mathbf{5}$, followed by a direct nucleophilic attack of the 11 hydroxyl, eventually in an ionised form, onto the oximic nitrogen with prior or concomitant release of tosylate anion (Fig. 2).

The second mechanism seems more likely to us on the basis of the following observations: i) the $E$ oxime 1 dissolved in acetone at $0^{\circ} \mathrm{C}$ in the presence of $\mathrm{KOH}$ does not show isomerization to the $Z$ oxime for at least 5 hours later; on the contrary the isomerization occurs at room temperature but the process is slow and takes some hours $^{5)}$ to reach the equilibrium; ii) the configuration of carbon $\mathrm{C}-11$ of the isoxazoline derivative 7 is the same as the starting $E$ oxime 1 . While the vicinal coupling constant $J(10,11)$ of $8.7 \mathrm{~Hz}$ is not conclusive for the elucidation of the relative stereochemistry of carbons C-10 and C-11, the large NOE enhancement observed between $\mathrm{H}-10$ and $\mathrm{H}-11$ ( $\mathrm{ca} .9 \%$ ) and the absence of NOE between $\mathrm{H}-11$ and $\mathrm{CH}_{3}-10$ strongly supports the assumption that hydrogens $\mathrm{H}-10$ and $\mathrm{H}-11$ are located cis on the isoxazoline ring. The lack of inversion of C-11 configuration rules out the $\mathrm{S}_{\mathrm{N}} 2$ type reaction suggested by the first mechanism. The second mechanism, leading to the formation of an isoxazoline ring is, as far as we know, very unusual. On the other hand this mechanism has been invoked previously ${ }^{8)}$ to explain the formation under the conditions of the Beckmann rearrangement of an isoxazoline ring in a steroidal scaffold probably due to conformational biases. It is reasonable to assume the same should be true also for our macrolide isoxazoline. In fact detailed conformational studies carried out on erythromycin oxime $^{9)}$ and a derivative $(E)-11-O-(2-$ dimethylaminoethoxy)methyl-9-deoxo-9-methoxyiminoerythromycin $A^{10)}$ indicated that the $C_{9}=N_{9}$ bond is almost parallel to the $\mathrm{C}_{11}-\mathrm{O}_{11}$ bond (the dihedral angle $\mathrm{O}_{11}-\mathrm{C}_{11}-\mathrm{C}_{9}-\mathrm{N}_{9}$ is less then $5^{\circ}$ ) and the distance $\mathrm{O}_{11} \cdots \mathrm{N}_{9}$ is about $3 \AA$, approximately the sum of the Van der Waals radii of the oxygen and nitrogen atoms. Such geometry together with the strong basic conditions of the reaction should favour formation of the oxygennitrogen bond instead of the usual Beckmann rearrangement.

Compound 7 shows extraordinary acid stability $\left(\mathrm{t}_{1 / 2}=24\right.$ hours at $\left.\mathrm{pH} 1\right)$ even in comparison with second generation macrolide antibiotics that were developed for their resistance to acidic decomposition, typical of this class of compounds. This stability could be of conformational origin and a study on the subject will be reported elsewhere.

\section{Experimental}

A solution of $10 \mathrm{~g}(13.37 \mathrm{mmol})$ of $E$-erythromycin oxime in $200 \mathrm{ml}$ of acetone at $0^{\circ} \mathrm{C}$ was treated with $53.48 \mathrm{mmol}$ of $\mathrm{KOH}$ dissolved in $50 \mathrm{ml}$ of water. After 5 minutes, $26.74 \mathrm{mmol}$ of $\mathrm{TsCl}$ dissolved in $50 \mathrm{ml}$ of acetone were added. After 1.5 hours at $0^{\circ} \mathrm{C}$ and 1.5 hours at room temperature the acetone was evaporated in vacuo and the residue partitioned between $\mathrm{CH}_{2} \mathrm{Cl}_{2}$ and water. The organic phase was separated, dried over $\mathrm{Na}_{2} \mathrm{SO}_{4}$ and evaporated in vacuo. The crude product was purified by Flash Chromatography $\left(\mathrm{CH}_{2} \mathrm{Cl}_{2}: \mathrm{MeOH}: \mathrm{NH}_{4} \mathrm{OH}\right.$ $90: 10: 1)$ giving 7 in $60 \%$ yield. $\mathrm{MS}(\mathrm{EI}): 730 . \mathrm{mp} 253^{\circ} \mathrm{C}$. $\alpha_{\mathrm{D}}=-125^{\circ}\left(c=1\right.$ in $\left.\mathrm{CH}_{2} \mathrm{Cl}_{2}\right)$. 
NMR Data for 7

${ }^{1} \mathrm{H}$ NMR $\left(\mathrm{CDCl}_{3}\right), \delta 2.97(\mathrm{dq}, 1 \mathrm{H}, \mathrm{H}-2, \quad J=3.9$, $7.4 \mathrm{~Hz}), 4.14(\mathrm{dd}, 1 \mathrm{H}, \mathrm{H}-3, J=1.8,3.8 \mathrm{~Hz}), 2.74(\mathrm{~m}, \mathrm{H}-4$, $J=1.5,7.5 \mathrm{~Hz}), 3.54(\mathrm{~d}, 1 \mathrm{H}, \mathrm{H}-5, J=8.2 \mathrm{~Hz}), 1.39(\mathrm{~d}$, $\left.1 \mathrm{H}, \mathrm{H}-7, J_{\mathrm{gem}}=13.6 \mathrm{~Hz}\right), 2.78\left(\mathrm{dd}, 1 \mathrm{H}, \mathrm{H}-7^{\prime}, J=11.1\right.$, $13.6 \mathrm{~Hz}), 2.59(\mathrm{~m}, 1 \mathrm{H}, \mathrm{H}-8, J=11.1,7.1,1.0 \mathrm{~Hz}), 3.59$ $(\mathrm{dq}, 1 \mathrm{H}, \mathrm{H}-10, J=7.5,8.6 \mathrm{~Hz}), 4.45(\mathrm{~d}, 1 \mathrm{H}, \mathrm{H}-11$, $J=8.6 \mathrm{~Hz}), 4.65(\mathrm{dd}, 1 \mathrm{H}, \mathrm{H}-13, J=1.9,11.2 \mathrm{~Hz}), 1.61$ $\left(\mathrm{m}, 1 \mathrm{H}, \mathrm{H}-14, J_{\text {gem }}=14.0 \mathrm{~Hz}, J=7.2,2.0 \mathrm{~Hz}\right), 1.93(\mathrm{~m}$, $\left.1 \mathrm{H}, \mathrm{H}-14^{\prime}, J_{\mathrm{gem}}=14.0 \mathrm{~Hz}, J=7.2,11.4 \mathrm{~Hz}\right), 0.91(\mathrm{t}, 3 \mathrm{H}$, $\left.\mathrm{CH}_{3}-14, J=7.1 \mathrm{~Hz}\right), 1.13\left(\mathrm{~d}, 3 \mathrm{H}, \mathrm{CH}_{3}-2, J=7.4 \mathrm{~Hz}\right), 1.10$ (d, $\left.3 \mathrm{H}, \mathrm{CH}_{3}-4, J=7.5 \mathrm{~Hz}\right), 1.24\left(\mathrm{~s}, 3 \mathrm{H}, \mathrm{CH}_{3}-6\right), 1.08$ (d, $\left.3 \mathrm{H}, \mathrm{CH}_{3}-8, J=7.3 \mathrm{~Hz}\right), 1.51\left(\mathrm{~d}, 3 \mathrm{H}, \mathrm{CH}_{3}-10, J=7.5 \mathrm{~Hz}\right.$ ), 1.14 (s, 3H, $\mathrm{CH}_{3}-12$ ), 4.37 (d, $1 \mathrm{H}, \mathrm{H}^{-1} \mathrm{l}^{\prime}, J=7.3 \mathrm{~Hz}$ ), 3.23 (dd, $\left.1 \mathrm{H}, \mathrm{H}-2^{\prime}, J=10.1,7.4 \mathrm{~Hz}\right), 2.46\left(\mathrm{~m}, 1 \mathrm{H}, \mathrm{H}-3^{\prime}\right.$, $J=10.2,3.9,12.3 \mathrm{~Hz}), 1.22\left(\mathrm{~m}, 1 \mathrm{H}, \mathrm{H}-4^{\prime} \mathrm{ax}\right), 1.68(\mathrm{~m}$, $1 \mathrm{H}, \mathrm{H}-4^{\prime}$ eq, $\left.J=1.8,3.9,14.4 \mathrm{~Hz}\right), 3.46\left(\mathrm{dqd}, 1 \mathrm{H}, \mathrm{H}-5^{\prime}\right.$, $J=1.8,6.1,10.6 \mathrm{~Hz}), 1.22\left(\mathrm{~d}, 3 \mathrm{H}, \mathrm{CH}_{3}-5^{\prime}, J=6.1 \mathrm{~Hz}\right)$, 2.31 (s, $\left.6 \mathrm{H}, \mathrm{N}\left(\mathrm{CH}_{3}\right)_{2}\right), 1.56$ (dd, $1 \mathrm{H}, \mathrm{H}-2^{\prime \prime}$ ax, $J=15.2$, $4.8 \mathrm{~Hz}), 2.41\left(\mathrm{~d}, 1 \mathrm{H}, \mathrm{H}-2^{\prime \prime}\right.$ eq, $\left.J=15.2 \mathrm{~Hz}\right), 3.02(\mathrm{dd}, 1 \mathrm{H}$, $\left.\mathrm{H}-4^{\prime \prime}, J=9.6,10.5 \mathrm{~Hz}\right), 4.03\left(\mathrm{dq}, 1 \mathrm{H}, \mathrm{H}-5^{\prime \prime}, J=9.2\right.$, $6.2 \mathrm{~Hz}$ ), 3.34 (s, $\left.3 \mathrm{H}, \mathrm{OCH}_{3}-3^{\prime \prime}\right), 1.24$ (s, $\left.3 \mathrm{H}, \mathrm{CH}_{3}-3^{\prime \prime}\right)$, $1.27\left(\mathrm{~d}, 3 \mathrm{H}, \mathrm{CH}_{3}-5^{\prime \prime}, J=6.2 \mathrm{~Hz}\right), 2.18\left(\mathrm{~d}, 1 \mathrm{H}, \mathrm{OH}-4^{\prime \prime}\right.$, $J=10.5 \mathrm{~Hz}$ ).

${ }^{13} \mathrm{C}$ NMR $\left(\mathrm{CDCl}_{3}\right), \delta 178.8(\mathrm{C}-1), 44.9(\mathrm{C}-2), 78.6$ (C-3), 42.7 (C-4), 82.4 (C-5), 37.4 (C-7), 26.2 (C-8), 168.3 (C-9), 45.3 (C-10), 85.1 (C-11), 82.6 (C-13), 23.0 (C-14), $11.4\left(\mathrm{CH}_{3}-14\right), 103.4\left(\mathrm{C}-1^{\prime}\right), 70.8\left(\mathrm{C}-2^{\prime}\right), 65.7\left(\mathrm{C}-3^{\prime}\right), 29.1$ (C-4'), $68.9\left(\mathrm{C}-5^{\prime}\right), 21.5\left(\mathrm{CH}_{3}-5^{\prime}\right), 40.4\left(\mathrm{~N}^{\prime}\left(\mathrm{CH}_{3}\right)_{2}\right), 95.4$ $\left(\left(\mathrm{C}-1^{\prime \prime}\right), 34.7\left(\mathrm{C}-2^{\prime \prime}\right), \quad 78.0\left(\mathrm{C}-4^{\prime \prime}\right), 65.5\left(\mathrm{C}-5^{\prime \prime}\right), 18.4\right.$ $\left(\mathrm{CH}_{3}-5^{\prime \prime}\right), 49.6\left(\mathrm{OCH}_{3}-3^{\prime \prime}\right), 21.4\left(\mathrm{CH}_{3}-3^{\prime \prime}\right), 13.6\left(\mathrm{CH}_{3}-2\right)$, $8.9\left(\mathrm{CH}_{3}-4\right), 29.3\left(\mathrm{CH}_{3}-6\right), 20.4\left(\mathrm{CH}_{3}-8\right), 10.0\left(\mathrm{CH}_{3}-10\right)$, $23.5\left(\mathrm{CH}_{3}-12\right), 75.8$ and 72.9 (signals due to the three quaternary carbons $\mathrm{C}-12, \mathrm{C}-6$ and $\mathrm{C} 3$ ", which were not assigned).

\section{References}

1) Lartey, P. A.; H. N. Nellans \& S. K. Tanaka: New developments in macrolides: Structures and antibacterial and prokinetic activities. Adv. Pharmacol. 28: $307 \sim 343$, 1994

2) Kirst, H. A.: Semi-synthetic derivatives of erithromycin. Progr. Med. Chem. 30: 57 88, 1993

3) Djokic', S.; G. Kobrehel, G. Lazarevsky et al:: Erythromycin series. Part 11. Ring expansion of erythromycin A oxime by the Beckmann rearrangement. $\mathbf{J}$. Chem. Soc. Perkin Trans. I: $1881 \sim 1890,1986$

4) YANG, B. V.; M. Goldsmith \& P. J. RizzI: A novel product from Beckmann rearrangement of erithromycin A 9(E) Oxime. Tetrahedron Lett. 55: 3025 3028, 1994

5) Wilkening, R. R.; R. W. RatCliffe, G. A. Doss et al.: The synthesis of novel 8a-aza-8a-homoerythromycin derivatives via the Beckmann rearrangement of (9Z)erythromycin A oxime. Bioorg. Med. Chem. Lett. 3: $1287 \sim 1292,1993$

6) Witanovsky, M.; L. Stefaniak \& H. Januzewsky: Nitrogen NMR, Witanowski, M. and WebB, G. A. Editors, Plenum Press, London, 1973

7) Chin Chen, B. W. von Philipsborn \& K. Nagarajan: ${ }^{15} \mathrm{~N}-\mathrm{NMR}$ spectra of azoles with two heteroatoms. Helv. Chim. Acta: 66: $1537 \sim 1555,1983$

8) Noguchi, S.; M. IMANishi \& K. Morita: Steroid [16,17-c] isoxazoline. Chem. Pharm. Bull. 12: $1189 \sim 1192,1964$

9) McGill, J. M. \& R. Johnson: Structural and conformational analysis of $(E)$-erythromycin A oxime. Magn. Res. Chem. 31: 273 277, 1993

10) Everett, J. R.; I. K. Hatton, E. Hunt \& J. W. Tyler: The conformational analysis of derivatives of erythromycin A. X-ray crystallographic and nuclear magnetic resonance spectroscopic studies of $(E)$-11-(2-dimethylaminoethoxy)methyl-9-deoxo-9-methoxyiminoerythromycin A. J. Chem. Soc. Perkin Trans. II: 1719 1728,1989 